\title{
A spatiotemporal model of spine calcium dynamics in the hippocampus
}

\author{
Thom Griffith $^{1 *}$, Jack Mellor ${ }^{2}$, Krasi Tsaneva-Atanasova ${ }^{3}$ \\ From 24th Annual Computational Neuroscience Meeting: CNS*2015 \\ Prague, Czech Republic. 18-23 July 2015
}

$\mathrm{Ca}^{2+}$-signalling in dendritic spines is required for NMDA receptor-dependent synaptic plasticity at glutamatergic synapses in the hippocampus [1]. However, it is not clear whether plasticity induction is dependent solely on the global signal, i.e., the spine volume-averaged $\mathrm{Ca}^{2+}$ signal; or whether plasticity induction is also sensitive to $\mathrm{Ca}^{2+}$-channel nanodomain signaling [2] A working hypothesis of this work is that temporal and spatial variations in postsynaptic intracellular $\left[\mathrm{Ca}^{2}\right.$ ${ }^{+}$]-fields may be significant factors governing the signalling cascades that lead to either long-term synaptic potentiation or depression. Direct measurement of $\left[\mathrm{Ca}^{2+}\right]$ distributions in dendritic spines is experimentally difficult but we can investigate this hypothesis using mathematical models of $\mathrm{Ca}^{2+}$ diffusion.

We have developed a spatio-temporal model of $\mathrm{Ca}^{2+}$ diffusion in three dimensions. We then study our model using finite element methods. The model allows predictions of intracellular $\left[\mathrm{Ca}^{2+}\right]$-field responses to combinations of pre- and post-synaptic spikes with nanometre and millisecond spatio-temporal resolution. Our results so far indicate that $\mathrm{Ca}^{2+}$ signalling is highly spatially non-uniform and that $\mathrm{Ca}^{2+}$ signal differences between induction protocols is dependent on location within the spine. This has implications for the ultimate biological role of the $\mathrm{Ca}^{2+}$ signal given that the relevant receptors in the spine are organised inhomogeneously [3].

\section{Acknowledgements}

Support for this work was provided by the EPSRC, UK (EP/1013717/1).

\section{Authors' details}

'Department of Engineering Maths, University of Bristol, Bristol, UK. ${ }^{2}$ School

of Physiology and Pharmacology, University of Bristol, Bristol, UK.

${ }^{3}$ Department of Mathematics, University of Exeter, Exeter, UK.

\footnotetext{
* Correspondence: thom.griffith@bristol.ac.uk

'Department of Engineering Maths, University of Bristol, Bristol, UK
}

Full list of author information is available at the end of the article
Published: 18 December 2015

\section{References}

1. Malenka RC, Bear MF: LTP and LTD: an embarrassment of riches. Neuron 2004, 44(1):5-21.

2. Chen $Y$, Sabatini BL: Signaling in dendritic spines and spine microdomains. Current Opinion in Neurobiology 2012, 22(3):389-396.

3. Mori MX, Erickson MG, Yue DT: Functional stoichiometry and local enrichment of calmodulin interacting with $\mathrm{Ca}^{2+}$ channels. Science 2004, 304(5669):432-435.

\section{doi:10.1186/1471-2202-16-S1-P268}

Cite this article as: Griffith et al:: A spatiotemporal model of spine calcium dynamics in the hippocampus. BMC Neuroscience 2015 16(Suppl 1):P268.
Submit your next manuscript to BioMed Central and take full advantage of:

- Convenient online submission

- Thorough peer review

- No space constraints or color figure charges

- Immediate publication on acceptance

- Inclusion in PubMed, CAS, Scopus and Google Scholar

- Research which is freely available for redistribution

Submit your manuscript at www.biomedcentral.com/submit
() Biomed Central

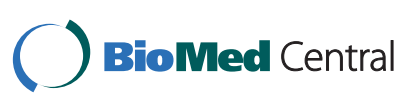

(c) 2015 Griffith et al. This is an Open Access article distributed under the terms of the Creative Commons Attribution License (http:// creativecommons.org/licenses/by/4.0), which permits unrestricted use, distribution, and reproduction in any medium, provided the original work is properly cited. The Creative Commons Public Domain Dedication waiver (http://creativecommons.org/publicdomain/ zero/1.0/) applies to the data made available in this article, unless otherwise stated. 